\title{
An Advantageous Proposition
}

\section{Dr Lucia Patrizio Gunning}

Department of History, University College London, London, United Kingdom

1.gunning@ucl.ac.uk

Lucia Patrizio Gunning is a teaching fellow at the Department of History, University College London, where she currently teaches the course: Collecting for the Nation, Amateurs, Collectors and Diplomats: A History of Museum Formation. She has a degree in Languages and Foreign Literatures from the University of L'Aquila in Italy and a $\mathrm{PhD}$ in History from University College London. Her book, The British Consular Service in the Aegean and the Collection of Antiquities for the British Museum (Ashgate 2009), provides the basis for her approach to research on the institutional role in the collection of antiquities. This role, the repercussions on today's attitudes toward cultural heritage, post-disaster reconstruction, and the position of museums in society, are the focus of her current research interests. 


\section{An Advantageous Proposition}

When in 1820 consul Henry Salt offered to sell Egyptian antiquities, including the Seti sarcophagus, to the British Museum, the British government was unprepared for the substantial investment required. The subsequent acquisition of the sarcophagus by John Soane was the catalyst in changing the government attitude to collecting antiquities for the national museum. The acceptance of a proposal made in 1835 by Giovanni D'Athanasi to excavate in Egypt turned the government from a passive recipient into an active collector of antiquities for its museum. These episodes provide insights into the mechanisms by which the British Museum's collection was established. They also illuminate how collecting by a national museum established an object habit that linked antiquities acquisitions, nationalism, and restitution demands in the twentieth and twenty-first centuries.

Keywords:

Museums, antiquities, restitution, heritage, provenance, collecting, Egypt, archaeology, consuls, nationalism, digital technologies 
In considering the 'Object Habit' it is important to understand how attitudes to collecting have changed and developed with the passage of time. Approaches that were possible and legal through the eighteenth and most of the nineteenth centuries are now both unthinkable and illegal. As attitudes to the gathering of collections have transformed, we have become more sensitive to the cultural importance of artefacts in their places of origin, and we should expect greater transparency about how objects came to be collected so that we can better understand the mechanisms which currently put cultural heritage at risk. This paper is a reflection on those attitudes. Examining one specific example illustrated by correspondence between a private agent and the trustees of the British Museum, the paper aims to show how the involvement of a number of governmental agencies was necessary for gathering and transporting monumental statues, friezes, and artefacts to the British Museum. That involvement, which is demonstrated in this correspondence and the presence of the monuments in the museum, has a bearing on the social, cultural, educational, political, and ideological aims that surrounded their collection. As times have evolved, those aims have changed, and yet the objects have remained attached to those early narratives. The object habit prompts us to look at the broader reasons and motives behind the collecting of such objects. What was it that, notwithstanding the perceived inferior attraction of the Egyptian antiquities, made them, at a specific point, a matter of national interest and of worth for the national museum? As identified in some of the correspondence, the acquisition by a competing power, specifically by the French, pushed the argument beyond the immediate understanding of the aesthetic or material value of the monuments into the need to acquire them for national interest. ${ }^{1}$,This became the issue that drove the object habit throughout the nine-

\footnotetext{
${ }^{1}$ F.O. 78/177, fol. 182, 2 November, 1827.
} 
teenth century and the focus of the narrative constructed around the acquisitions. The examples chosen here highlight this. In these obvious ideological conflicts it is the study of original correspondence relating to acquisitions that allows us to interpret the motives behind the collections, clarify the circumstances that led to the acquisition of the pieces and face up to the legacy of the object habit and the challenges of the present day. It is in the capacity to open up and reconsider those transactions that the future of the archaeological (and encyclopaedic) museum lies, say Markus Hilger and France Desmarais, ${ }^{2}$ and with Brexit some of those conversations might have to be uncomfortably addressed..$^{3}$

In 1820 Henry Salt, British consul general at Alexandria, offered to sell to the British Museum a number of monumental statues excavated in Egypt. Salt had been appointed Levant Company consul in 1815 , and had received semi-official requests from Sir Joseph Banks and the Society of Antiquarians to excavate on behalf of the British Museum. ${ }^{4}$ Teaming up with Giovanni Belzoni, he had managed to put together a significant collection. The offer to the British Museum however, had been approached in the wrong way as Salt had put a price to the pieces, which had sent quite the wrong mes-

2 Markus Hilger and France Desmarais, 'From Collecting to Protecting. The Role of the Archaeological Museum in Safeguarding Heritage', ICOM News 2015 Vol. 68 n.3-4, December 2015, pp.24-5.

3 Geoffrey Robertson: Let's do a Brexit deal with the Parthenon marbles, The Guardian, 04/04/2017. https://www.theguardian.com/commentisfree/2017/apr/04/brexit-dealparthenon-marbles

4 'The expense of the undertaking, whether successful or otherwise, ... would be most cheerfully supported by an enlighten'd nation, eager to anticipate its Rivals in the prosecution of the best interests of literature and science', F.O. 24/6, fol. 66, in Maya Jasanoff, Edge of Empire. Conquest and Collecting in the East, 1750-1850. (2006), p. 238. 
sage..$^{5}$ As Stephanie Moser points out, Egyptian antiquities were seen as a less prestigious acquisition than the Greek or Roman ones, and thus less appetising: their appearance was unfamiliar, their value undefined, and their civilisation yet unstudied. 'Colossal monstrosities' and 'accessible oddities' were two definitions which Moser quotes to describe how such antiquities were perceived during the nineteenth century. The price they could command was unclear. ${ }^{6}$ Attaching a value to the antiquities had offended the trustees and furthermore the sum requested was considered excessive. ${ }^{7}$ And yet, the most significant factor was that the trustees remained unclear on the role of the Museum at this stage. Was it to be a pro-active acquirer of antiquities? Or should it rather remain content to receive only those donated generously? That the French appeared to value the same antiquities for their museum did not seem to matter too much, until a number of them were actually sold to the Louvre by Salt himself. 8 Amongst the Foreign Office papers for 1827 , one concernedly explains that Salt did not seem aware of the great interest 'felt in this country for Egyptian antiquities' and as a consequence many had been

5 Stephanie Moser, Wondrous Curiosities. Ancient Egypt at the British Museum (Chicago: University of Chicago Press, 2006), p.101.

6 Stephanie Moser, Wondrous Curiosities, pp.94-105.

7 Lucia Patrizio Gunning, The British Consular Service in the Aegean and the Collection of Antiquities for the British Museum ((London and New York: Routledge, 2009), pp.8-11; Stephanie Moser, Wondrous Curiosities, (2006), p.96.

8 'From some late transactions it would appear that Mr. Salt is not accurately informed of the great interest which is felt in this country for Egyptian Antiquities, and that we have consequently lost many objects of great importance which have been eagerly obtained by [the] French Government. I trust therefore that your Lordship will excuse my bespeaking your influence with Mr. Salt and our other consuls that our national Museum may be enriched by many interesting objects which may be in their power to obtain; and that our collection of Antiquities and of Natural History may be unrivalled, as our opportunities and facilities exceed those of any other Nation', F.O. 78/177, fol. 182, 2 November, 1827, in: Gunning, The British Consular Service, p. 10. 
lost to the French, urging the ambassador to exert his influence with this unruly consul and others in the region to acquire objects 'that are in our power to obtain' for the national museum. One gets a sense that it was due to this tactical mistake that his second and more important offer was turned down. ${ }^{9}$

When Belzoni discovered the sarcophagus of Seti, a unique one-piece carved alabaster and semi-transparent monumental coffin, he saw his legacy as dependent on the placing of this important object within the British Museum. However, the acquisition was never agreed, once again the price being the contentious point, as Salt demanded at least $£ 3000$ with any sum above $£ 2000$ being split between him and Belzoni. Sir Joseph Banks, who had been instrumental in sending Salt to Egypt, had believed that he would be able to convince the government to accept Salt's antiquities, and so had Salt. When, however, the Treasury refused to provide the money for the acquisitions, despite the museum having offered the same sum some time before, Salt sold the sarcophagus to the architect and collector John Soane. By then Belzoni had died and his widow was excluded from the transaction. ${ }^{10}$

'I am sorry to say in connection with this subject that Mr S.[alt] employed the power entrusted to him by Government entirely for his own advantage and to the exclusion of other parties, engaging in a kind of trading monopoly in conjunction with Sig. Drovetti in a manner not very creditable to either the individuals or their Governments.', Catherwood to Hawkins, in Middle East Department, British Museum: M.E. Letter book n. 1, new series, fol. 72, 24 august 1835, in: Gunning, The British Consular Service, p. 10.

10 A consequence of this was that Belzoni's widow Sarah did not receive any money from the transaction as the sarcophagus was sold to Soane for just $£ 2000$.

Neil Chambers, Joseph Banks and the British Museum: the World of Collecting, 1770-1830, (London, Chatto, 2007), pp.124-6; Moser, Wondrous Curiosities, (2006), pp. 103-4. 
When, on 11 July 1835, a letter landed on the desk of Edward Hawkins, then director of the Department of Antiquities at the British Museum, the episode of the sarcophagus became relevant once again. Signed by Giovanni D’Athanasi, who had worked in Egypt with Belzoni and as an agent for Salt, the letter informed Hawkins that the writer was aware of the potential for new excavations, as well as the painful lack of a respectable collection of Egyptian antiquities at the British Museum. Having been for 'a long time urged to it by many English Travellers who had regretted to see their National Museum in need of many fine articles which went to furnish the Galleries of other Countries', D'Athanasi made Hawkins what he called an 'advantageous proposition': he not only offered his expertise to 'supply the British Museum with the most beautiful specimen of Egyptian Antiquities, so as in five years to put it in condition to rival the Museum at Paris', but proposed to get enough antiquities to sell the 'doubles' on the open market so as to recover part of the expenses. He asked to be paid $£ 1500$ for each year of engagement and to receive letters of recommendation to the consuls of Great Britain in Egypt, so to procure the 'aid and protection of the local Government' famously jealous of its antiquities. ${ }^{11}$

Acutely aware of the previous refusals by the government, Hawkins decided on this occasion to intervene personally to lobby the trustees from within. He thus prepared a letter that he sent to each separately on 18 August. In it, he explained that D'Athanasi, employed by Salt in Egypt, had offered his services to the British Museum, and that many who had been in Egypt and consulted on the project, had deemed the plan feasible and successful. Hawkins was worried that, as the government had never engaged in un- 
dertakings of this nature, D'Athanasi's offer might be declined and his services offered to the French. So he prepared a set of questions to be answered by each trustee:

How far it is reasonable to expect, that excavations will produce Objects commensurate in value with the probable expense? Is Athanasi competent to the undertakings he proposes? Is he trustworthy? .... What is the more effectual mode of securing a proper expenditure of the money and of the certain transfer to England of all the objects discovered?

Hawkins canvassed their suggestions and asked if they could bring this matter to the 'attention and consideration' of the Lords of the Treasury. ${ }^{12}$ Because the trustees included in their number so many senior members of the government itself, 13 D'Athanasi's proposal and subsequent engagement may be understood as a matter undertaken by British government representatives with the aim of enriching the Egyptian collection for the national museum. ${ }^{14}$

12 Hawkins, Circular, M.E., Letter book n. 1, new series, fol. 68, 18 Aug. 1835.

13 British Museum, Statutes and Rules of the British Museum (1932), p. 21.

14 A second letter from D'Athanasi was even more specific and it dispels any remaining doubts about the nature of the arrangement. The agent made three different proposals, leaving to the trustees choice on the amount to spend and explaining the impact that this would have on the monumental statue on offer. The statue could be cut 'in three equal portions', be taken to the seaside at Alexandria and from there transported to England by one of the vessels already in the Mediterranean, this would cost $£ 1000$, being $£ 800$ for expenses plus $£ 200$ of remuneration, if however there was no desire to have the statue cut, the cost would be higher. In this second case the transport to Alexandria would cost $£ 1500$. The final alternative: 'It would cost an enormous sum to obtain it entire, I will undertake to remove it from the place in which it now stands and deliver it in the courtyard of the British Museum for the sum of $£ 5000$ '. D’Athanasi to Hawkins, M.E., Letter Book n.2 Old Series, folio 126, 29 June 1837. 
The government was not only involved in examining the offer, it subsequently decided on the appropriate expenditure, purchase authorisation, and provision of government employees to facilitate the statue's delivery to the British Museum. Further, a number of governmental agencies became, almost by chance, active collaborators in this enterprise: the British consul in Egypt, the Navy, and in later years the Customs House. More importantly it should be underlined that, however unintentionally, from the moment the British government committed money to the procurement of antiquities, it stopped being simply the grateful receiver of gifts and instead became a proactive agency in support of its national museum. As the activation of official channels was the key to speediness and economy, the consular service began to be used with ever-increasing success for antiquities acquisitions. This process was later institutionalised by Charles Thomas Newton, the former British Museum employee and future Keeper of the Greek and Roman Antiquities Department, when he arrived as British vice consul in the Aegean in 1853.15 The leverage afforded to diplomats and consuls during the waning years of the Ottoman Empire, and the economy provided by the use of naval personnel and vessels, were instrumental in changing the British Museum from a haphazard assemblage of collections into a comprehensive and world-class institution.

In recent years, faced with increasing requests for the return of a number of particularly important works, the British government has avoided engagement in discussions on the issue of restitution. Many archaeologists, on the other hand, support the rights of originating countries to use their antiquities for their own benefit, to retain their cultural history, strengthen their tourist industry and reinforce their own national claim.

15 Gunning, The British Consular Service, chapter 4. 
On the other side, museum directors, with Cuno as the most vocal representative, advocate that museums have the right to possess such objects, and the right of all humanity to a shared past. Indeed, since his first controversial publication on the position of museums in the modern world, Cuno has successfully managed to shift the debate on the ethical side of our own history of collecting to a whole new ground. Against the background of ever-increasing claims for restitution, he has become a vocal campaigner of the right of westernised countries to hold encyclopaedic museums, believing that understanding the similarities between cultures under one roof is key to the promotion of a shared culture, and stating that we benefit more by the exchange of such cultures and from the understanding and interaction that this offers us all.16 Cuno decries the segregation of culture within national borders, and instead has argued that societies and nations should be working together for the preservation of the common heritage, reiterating the element of 'chance' in the location of antiquities. ${ }^{17}$ He bolsters his argument by asserting that there is no connection between the modern nation states and the cultures and civilisations that created the artefacts, defining this chance as an 'accident of geography' that led modern nation states to be geographically in the territory of ancient societies. ${ }^{18}$ His point on nationalist retentionist cultural property laws is particularly striking and one that resonates when reflecting on the significance of cultural heritage in today's complex reality; in many ways, it reflects nineteenth-century attitudes to the 'modern'

\footnotetext{
16 James Cuno, Whose Culture? The Promise of Museums and the Debate over Antiquities, (Princeton University Press, 2009), p.X.

17 Cuno, Who Owns Antiquity?, p.20.

18 Cuno, Who Owns Antiquity?, p.124.
} 
inhabitants of the great, ancient, empires. ${ }^{19}$ However, Cuno's argument that retentionist laws serve the interest of one nation 'at the expense of the rest of the world' is provocatory and divisive because it denies the primary right of provenance countries to use their own heritage for the benefit of their society. It is now understood that communities do benefit from the retention of their cultural heritage and to deny that right in today's open and increasingly globalised world creates tensions and reiterates the prevarications of the past. ${ }^{20}$

In the opening notes to State Succession in Cultural Property, Andrzej Jakubows ki, quoting Peter Wagner contradicts Cuno's analysis by pointing out that history is a narrative that is linked to both heritage and origins. What is 'remembered as origin(s), is constructed into the identity's heritage'. Can we really separate the individuals from the place they were born and bred, or from the places they grew up in, and the heritage around them that informed their perception of themselves and the world? For Jakubowsky history is not an objective, independent force, rather a process where decisions are reflections of a place and time. People are a result of that interaction. ${ }^{21}$ This includes heritage, which can be seen both as a result of that interaction and as an deci-

19 Cuno, Who Owns Antiquity?, p.146. See also p.11 and the Introduction of the same book. 'Nationalist retentionist cultural property laws serve the interests of one particular modern nation at the expense of the rest of the world. Antiquities are ancient artefacts of times and cultures long preceding the history of the modern nation-state. And in all but a very few cases, they have no obvious relation to that state other than the accident of geography: they happen to have been found within its modern borders.'

20 Unesco \#United4Heritage Conference, Brussels, 9-10 June 2016. See also Deepak Chhabra, Sustainable Marketing of Cultural and Heritage Tourism (London and New York: Routledge, 2010).

21 Peter Wagner "From Monuments to Human Rights: Redefining "Heritage" in the Work of the Council of Europe', in State Succession in Cultural Property, ed.by Andrzej Jakubowski (Oxford: Oxford University Press, 2015), p. 1. 
sive element in the formation of the individual in a particular place and at a particular time.

In excusing modern nation states as nineteenth-century creations, Cuno and other museum professionals conveniently forget that, historically, many museums were nineteenth-century products, representatives of nation states and former empires that formed their own national identities using the artefacts of others. European nation states and their museums, in particular, as the institutions we know today, were inextricably linked to the concept of empire and the objects in their collections were excavated and imported under circumstances that were often instrumental in forming imperial identity and strengthening the object habit of associating those ancient artefacts with national interests. $^{22}$

Preziosi instead criticises museum professionals for the 'abandonment of critically engaged and historically responsible attention to fundamental questions about the functions and social and political role' of museums. ${ }^{23}$ After decades of public debate on the role of the museum in society, most museums' collections policies have not changed and some continue to evince an imperialist attitude. Criticising Neil MacGregor's stance on the Elgin marbles directly, Preziosi enquires why, if the artefacts are really part of a story that transcends nationality, that story cannot be told equally appropriately from Athens, Cairo or Bagdad. He points out that there is no reason, and no evidence, that the

22 Brian Dolan, Exploring European Frontiers. British Travellers in the Age of Enlightenment, (Basingstoke and New York: Palgrave Macmillan, 2000), p.149.

23 Donald Preziosi, Philosophy and the End of the Museum, in: Museum Philosophy for the Twenty first Century, ed. Hugh H.Genoways (New York: AltaMira Press, 2006), pp.70 and 78. 
story should be more legible from London than Athens. ${ }^{24}$ And if the purpose of the museum is to tell a story, 'whose' story, for what purpose, and to which end are these stories being told? For Preziosi, the museum is itself an act of fiction, one that 'in (re)presenting itself as historically real ... functions precisely as theater ... creating the 'effects' of the (historically) real.' 25 Thus the question as to what should be held in trust for the world, by whom, for how long and why, are not being addressed but rather dismissed with the simplistic facade of the 'museum for the world' ${ }^{26}$

Beyond the theoretical analyses presented here, one is aware that other factors The persistence of national interests in debates over the restitution of antiquities comprises the one object habit that has continued to influence points of view and perceptions. In the arguments concerning the Elgin marbles, for example, national interests persist as the highest point of association with this extraordinary set of monuments. Arguably, the artistic value and beauty of the marbles, the importance of the context, the reintroduction into a different yet continuing narrative of the newly built museum in Athens, have all been overlooked in favour of the issue of British national interest. As settling the dispute on the basis of a legal argument would present obvious problems linked to the interpretation of the firman whose original has been lost, on the Greek side the marbles have been identified as 'a key symbol of Greek cultural heritage and national identity'. ${ }^{27}$ Ironically therefore, the past thirty years of debate have reinforced that

\footnotetext{
24 Preziosi, 'Philosophy’, p.74.

25 Preziosi, ‘Philosophy', pp.74-5

26 Preziosi, 'Philosophy', p.75.

27 Gregor Kleinknecht and Katerine Bagerman, Klein, Art Solicitors, London, 'The Elgin Marbles - A Classical Repatriation Saga Explained', Art \& Cultural Heritage Law Newsletter, Fall 2008, vol.1, IV, p.7.
} 
very object habit that the two countries have been trying to reverse. The beauty, history and artistic significance of the marbles have all been forgotten in favour of which country's national interest has a stronger claim.

Plenty of historians have written about the emergence of the western empires through the cultures of the countries they conquered and the artefacts they appropriated. Brian Dolan, for instance, drew attention to Napoleon's campaign, during which 'an imperial discourse developed which was laden with justifications for collecting antiquities which themselves became emblems of the empire'. Embedded in a new context aimed at creating new political values and a new identity, the British saw Napoleon's defeat in Egypt and the consequent acquisition of the antiquities collected there by the French, as 'an expression of political and civil triumph over radical and corrupt French tyranny'.28 Military spoils became the rightful property of the state and a convenient source of museum contents. As Preziosi points out, the French had a clear intent of reeducating the peasantry in the 'techniques, protocols and ceremonials of citizenship' of the republic. Patrimony was staged as collective in clear opposition to the exclusive, the citizen was invited to share the 'grandeur of the collective' within the 'newly minted' history of the republic. ${ }^{29}$ Thus in France the discourse was clearly stated. In Britain, the national museum had yet to acquire the same sense of purpose and, in many ways, D'Athanasi's proposition to the British Museum came at a crucial point. The proposition, and Hawkins' correspondence with the trustees, marked a pivotal moment when the British government first began actively to expand the national museum. Where the French Republic identified itself as a reincarnation of the Roman Republic, London por- 
trayed itself as the new Athens. Indeed, as Curti has highlighted, after the acquisition of the Parthenon marbles, large parts of London were redesigned in the neoclassical fashion, with the Athenian imaginary becoming a new and stronger symbol of identification for the state and its people. 30 This view is shared by Challis who has noted that the 'cultural inheritance of ancient Greece ... played a role in informing a notion of Britishness in the early nineteenth century'. ${ }^{31}$ For Preziosi, MacGregor's claim that the British Museum 'was in large measure removed from the political realm' is 'patently false' not only due to the very nature of the museum trustees' body, but because the message that the museum conveyed to the nation was essentially political. ${ }^{32}$ In her analysis of eighteenth-century Britain, Kathleen Wilson also contends that the discourses of 'patriotism were complicit with those of imperialism'. The formation of the citizen and a sense of entitlement both justified the acquisitions and were reinforced by the presence in Britain of the artefacts themselves. The discourse erased, or rather mystified, the 'exploitation and bloodshed at home and abroad through which imperial dominance was achieved and perpetuated'. Citizens were told one side of the story of imperialism, the one that justified the means to the end. Artefacts in museums proved that narrative. ${ }^{33}$

30 Emmanuele Curti, 'Re-inventing Pheidias: Athens, Modern Britain and the Politics of Culture', Neale Lecture, University College London, 3-4th March 2000, unpublished.

31 Deborah Challis, 'The Parthenon Sculptures: Emblems of British National Identity', The British Art Journal, Vol. 7, No. 1 (Spring/Summer 2006), pp. 33-39.

32 Preziosi, 'Philosophy,' p.73.

33 Kathleen Wilson, 'The Good, the Bad, and the Impotent. Imperialism and the Politics of Identity Georgian England' in: The Consumption of Culture 1600-1800. Image, Object, Text, ed. by Ann Birmingham and John Brewer, (London and New York: Routledge, 1997), p.255. 
Contemporary cultural and political crises and emerging digital technologies present an opportunity to reassess this particular object habit. 3D scanning and printing technologies allow the production of highly accurate facsimiles of archaeological remains and artefacts. The controversial reconstruction of the Palmyra arch by the Institute of Digital Archaeology has shown that it is possible to replicate even lost cultural heritage in a different context. 34 The Ur Online Project, a collaboration between the British Museum and the Penn Museum supported by the Levy Foundation, digitally 'reunifies' finds from the Mesopotamian city of Ur. ${ }^{35}$ Both these examples play with the narrative associated with the monuments and look for a reinterpretation, a modernisation, rather, of the story. If a sufficiently accurate stone replica is made of Pheidias's sculptures, does it really matter whether the original is located in a museum in London or Athens or even on the Acropolis itself? The Parthenon marbles have a story that is longer than the history of the museum that has been their home for the past 200 years (they were first displayed in the British Museum in 1817; sadly the controversy over their ownership seems to prevent a celebration for the second centenary of their arrival); it is difficult to imagine that this is where their story ends. ${ }^{36}$

34 Umberto Bacchi, 'Palmyra Arch in London: "Unethical" reconstruction of "Disneyland" archaeology criticised'. International Business, 20 April 2016, http://www.ibtimes.co.uk/ palmyra-arch-london-unethical-reconstruction-disneyland-archaeology-criticised-1555659 [accessed 25 April 2017]. See also the opposite point of view in: Nigel Richardson, 'The Arch of Triumph of Palmyra is recreated in London - 1,800 years after it was built'. The Telegraph, 18 April 2016, http://www.telegraph.co.uk/news/2016/04/08/why-the-arch-oftriumph-of-palmyra-is-being-recreated-in-london/ [accessed 27 April 2017]. Birger Helgestad and Jonathan Taylor, 'Ur of the Chaldees. A Virtual Vision of Woolley's Excavations' http://www.britishmuseum.org/research/research_projects/all_current_projects/ur_project.aspx [accessed 25 April 2017].

36 British Museum, 'The Parthenon Sculptures' http://www.britishmuseum.org/about_us/ news and_press/statements/parthenon_sculptures.aspx [accessed 25 April 2017]. 
The episode of D'Athanasi's proposal to the British Museum and the way in which Hawkins approached the trustees shows that there is more to museum history than a simple gathering of objects from different cultures. It helps us understand that the narrative constructed around the antiquities has influenced our understanding of them ever since. If we want to change the current status quo, we need to start to open up that history to understand what motivated the individuals involved and how instrumental governments were in the processes of procurement. Digital technologies have already started to challenge those narratives and can perhaps offer the key to a reinterpretation of their future. 